\title{
Chemical characterization of the flour of peel and seed from two papaya cultivars
}

\author{
Cláudia Mendes dos SANTOS ${ }^{1 \star}$, Celeste Maria Patto de ABREU², Juliana Mesquita FREIRE³ \\ Estela de Rezende QUEIROZ ${ }^{2}$, Marcelle Mendes MENDONÇA ${ }^{4}$
}

\begin{abstract}
Papaya is among the currently most important tropical fruits grown in Brazil and in the world. The fruit is mainly consumed fresh although it offers many industrial products. The processing of this fruit, as well as its fresh consumption, results in large amounts of waste, such as peels and seeds. Papaya consumption is one of the causes of significant loss of food value; therefore, new aspects on the use of its waste as by-products, or in the production of food additives, or even the incorporation of its flour in food have aroused great interest because these are products of high nutritional value, and their use may be economically viable. The objective of this study was to produce and characterize peel and seed flours from two papaya cultivars (Havai and Calimosa) for their chemical constituents focusing on possible use in foods. The proximate and mineral composition, titratable acidity, soluble solids, $\mathrm{pH}$, contents of vitamin $\mathrm{C}$, and phenolic compounds were determined. According to the results obtained, the papaya peel and seed flours had high contents of protein and fiber and therefore can be used as alternative sources of nutrients and can also be added in foods avoiding waste and adding value to the fruit.
\end{abstract}

Keywords: Carica papaya L.; by-product; use.

\section{Introduction}

Fruit processing results in large amounts of waste such as peels and seeds. The disposal of these materials is usually a problem, which is compounded by legal restrictions. Thus, new aspects on the use of this waste as by-products, for a further utilization in the production of food additives or supplements with high nutritional value, have aroused great interest since they are high-value products and their recovery may be economically attractive. It is known that by-products are important sources of sugars, minerals, organic acids, fiber, and phenolic compounds that have a wide range of pharmacological activities, which include antitumor, antiviral, antibacterial, cardioprotective, and antimutagenic activities (Djilas et al., 2009).

Making full use of food is a way to increase daily cooking by creating new recipes such as jellies, pies, juice, and pastries, in addition to nutritionally enriched diets, providing more fiber, vitamins, and minerals (Storck et al., 2013).

Papaya is one of the most common fruits in almost all countries in tropical America, and it was discovered by the Spanish in the region between southern Mexico and northern Nicaragua. After its discovery, papaya was widely spread in many tropical regions, extending to $32^{\circ}$ north and south latitude, with a possible introduction in Brazil in 1587. It is considered one of the most cultivated and consumed fruits in tropical and subtropical regions in the world. The fruit is an excellent source of calcium, pro-vitamin $\mathrm{A}$, and vitamin $\mathrm{C}$ (ascorbic acid); thus, it is widely used in diets (Serrano \& Cattaneo, 2010). Brazil is the second largest world producer of papaya, accounting for $19 \%$ of the total production (Informa Economics FNP, 2011).
Information about the chemical composition of unconventional foods such as papaya peel and seeds is still quite scarce and, therefore, the use of residues may be an alternative to help diet supplementation or incorporation as flours in food manufacturing.

In general, the use of food parts usually discarded by industries adds nutrients to various preparations. Storck et al. (2013), elaborated preparations using papaya seed cake and papaya peel jam and observed an increased fiber content and sensory analyses were conducted.

This study was conducted with the objective to produce and analyze papaya waste (peel and seed) flour for its chemical constituents with the purpose to use it in preparations and formulations of new products, adding more value to the fruit and preventing environmental pollution.

\section{Materials and methods}

Papaya fruits from the cultivars Calimosa and Havai were acquired from the Fresh Fruit and Vegetable Supply Center of Minas Gerais (CEASA/MG - Centrais de Abastecimento de Minas Gerais, MG) and transported to the Biochemistry Laboratory in the Chemistry Department at the Federal University of Lavras. They were selected according to the ripening stage (completely yellow peel, when the fruit is suitable for consumption), to color uniformity, average size, and absence of defects. The fruits selected were washed and sanitized with a $200 \mathrm{ppm}$ sodium hypochlorite solution. They were then manually peeled; the peels were cut and the seeds were

\footnotetext{
Received 20 Feb., 2014

Accepted 15 Apr., 2014 (006296)

1 Agrochemistry, Universidade Federal de Lavras - UFLA, Lavras, MG, Brasil, e-mail: claumsantos@yahoo.com.br

2 Chemistry Department, Universidade Federal de Lavras - UFLA, Lavras, MG, Brasil

3 Agrochemistry, Chemistry Department, Universidade Federal de Lavras - UFLA, Lavras, MG, Brasil

${ }^{4}$ Food Engineering, Universidade Federal de Lavras - UFLA, Lavras, MG, Brasil

${ }^{*}$ Corresponding author
} 
removed and washed with running water to remove mucilage. Subsequently, the peels and seeds were spread on trays and were oven-dried at $45^{\circ} \mathrm{C}$ for four days. After drying, the samples were ground using a TECNAL mill (TE-631); fine flour was then obtained and placed in sealed containers for further analyses.

A completely randomized design $(\mathrm{CRD})$ in a $(2 \times 2 \times 5)$ factorial scheme was used. The first factor was composed of the two cultivars (Calimosa and Havai) and the second factor of the by-products (peels and seeds) with 5 replicates of 5 fruits each. The results were subjected to variance analysis using the $\mathrm{R}$ ( $\mathrm{R}$ Core Team, 2013) software program, and the means were compared by the Tukey test at $5 \%$ probability.

Humidity, lipids (ether extract), crude protein $(\mathrm{N} \times 6.25)$, ash, and dietary fiber were quantified in the dried samples using the official methods described by the Association of Official Agricultural Chemists, AOAC (Association of Official Analytical Chemists, 2012). Nitrogen-free extract (glycidic fraction) was determined by the difference between $100 \%$ and the amount of humidity, ether extract, crude protein, ash, and dietary fiber. The minerals (Fe, $\mathrm{Zn}, \mathrm{Mn}, \mathrm{Cu}, \mathrm{Ca}, \mathrm{Mg}$, $\mathrm{P}, \mathrm{K}$, and $\mathrm{S}$ ) were determined according to the methodology described by Malavolta et al. (1997). The extract for mineral analyses was obtained by nitric-perchloric digestion (hot acid), adding a mixture of $\mathrm{HNO}_{3}$ and $\mathrm{HClO}_{4}$ to the ratio $2: 1(\mathrm{v} / \mathrm{v})$. The macronutrients $(\mathrm{Ca}$ and $\mathrm{Mg}$ ) and micronutrients $(\mathrm{Fe}, \mathrm{Zn}$, $\mathrm{Mn}$, and $\mathrm{Cu}$ ) were determined using an atomic absorption spectrophotometer (SpectrAA 110, Varian, USA) with the respective hollow cathode lamps. Atomic absorption standard solutions were used for the construction of calibration curves. An emission flame photometer (B262, Micronal, Brazil) was used in the determination of the macronutrient $\mathrm{K}$, while $\mathrm{P}$ and $S$ were analyzed using a UV-visible spectrophotometer (Lambda 25 Spectrometer, PerkinElmer, USA).

The content of vitamin $\mathrm{C}$ was determined by the colorimetric method described by Strohecker \& Henningg (1967). Phenolic compounds were quantified using the Folin-Denis reagent, which was reduced to a blue complex by phenols in an alkaline solution, and it was measured at $760 \mathrm{~nm}$ (Association of Official Analytical Chemists, 2012). The results were expressed as $\mathrm{mg}$ tannic acid $\mathrm{g}^{-1}$ sample.

Soluble solids were determined using a digital refractometer (ATAGO PR-100), and the $\mathrm{pH}$ using a glass electrode potentiometry (Association of Official Analytical Chemists, 2012). The total acidity was determined by titration with $0.1 \mathrm{~mol}$ $\mathrm{L}^{-1} \mathrm{NaOH}$, in accordance with Instituto Adolfo Lutz (2005). The results were expressed in percentage of citric acid.

\section{Results and discussion}

The results of the proximate composition obtained for papaya waste (peel and seed) flour are shown in Table 1.

The moisture content found for the peel flour from papaya

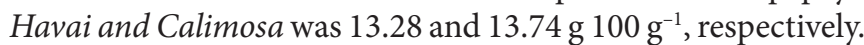
On the other hand, the moisture content found for the seed flour

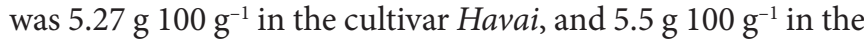
cultivar Calimosa. The peel flour from both cultivars had higher moisture content than that of the seed flour from both cultivars.

Regarding the ash content, there was no significant difference between the cultivars for the peel flour and the seed flour. The peel flour showed a higher content of this parameter for both cultivars. Silva et al. (2007) studied papaya at two ripening stages and observed values similar to those found

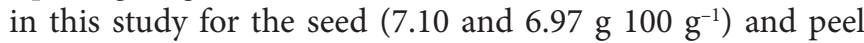

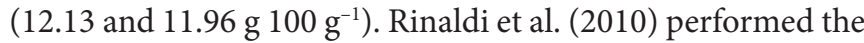
chemical characterization of papaya peel and seed from the cultivars Papaya and Formosa, and obtained levels of 7.75 and

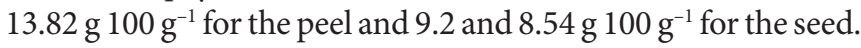

A higher amount of ether extract for the seed flour was observed, and there was no variation for the peel flour in the cultivars. Silva et al. (2007) reported values of 17.97 and $22.45 \mathrm{~g}$

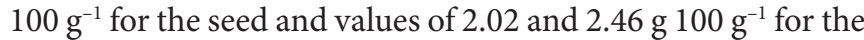
peel,which are consistent with those found in the present study.

The protein content in the seed flour, which was about $28 \mathrm{~g}$ $100 \mathrm{~g}^{-1}$, did not change significantly in the cultivars, and for the

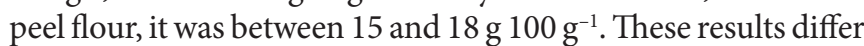
from those found in papaya seed and peel by Silva et al. (2007), who reported values between 17 and $19 \mathrm{~g}$ protein in the seed and 6 to $9 \mathrm{~g}$ in the peel. On the other hand, Rinaldi et al. (2010) found higher values for Formosa and Papaya peels: 25.35 and $32.5 \mathrm{~g}$

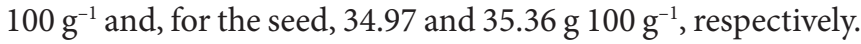
These differences may be due to differences among cultivars.

The high content of dietary fiber is noteworthy, especially in the papaya peel flour from both cultivars (Table 1). These results show the importance of the peel as a source of dietary

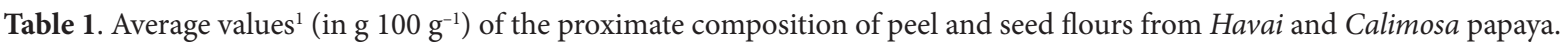

\begin{tabular}{|c|c|c|c|c|}
\hline & \multicolumn{2}{|c|}{ Havai } & \multicolumn{2}{|c|}{ Calimosa } \\
\hline & Peel & Seed & Peel & Seed \\
\hline Humidity & $13.28 \pm 0.64 \mathrm{a}$ & $5.27 \pm 0.17 \mathrm{~b}$ & $13.74 \pm 0.68 \mathrm{a}$ & $5.50 \pm 0.28 \mathrm{~b}$ \\
\hline Ash & $11.85 \pm 0.68 \mathrm{a}$ & $6.94 \pm 0.29 \mathrm{~b}$ & $11.31 \pm 0.13 \mathrm{a}$ & $7.53 \pm 0.33 \mathrm{~b}$ \\
\hline Lipids & $2.44 \pm 0.25 \mathrm{c}$ & $29.72 \pm 0.37 \mathrm{a}$ & $2.07 \pm 0.01 \mathrm{c}$ & $27.99 \pm 0.25 \mathrm{~b}$ \\
\hline Protein & $18.18 \pm 0.29 b$ & $28.55 \pm 0.50 \mathrm{a}$ & $15.03 \pm 0.41 \mathrm{c}$ & $28.09 \pm 0.56 \mathrm{a}$ \\
\hline Soluble fiber & $6.95 \pm 0.25 \mathrm{~b}$ & $5.44 \pm 0.13 c$ & $7.88 \pm 0.15 \mathrm{a}$ & $5.24 \pm 0.11 \mathrm{c}$ \\
\hline Insoluble fiber & $26.10 \pm 0.56 b$ & $3.36 \pm 0.05 c$ & $26.82 \pm 0.48 \mathrm{a}$ & $2.51 \pm 0.07 \mathrm{~d}$ \\
\hline Total fiber & $33.05 \pm 0.70 \mathrm{~b}$ & $8.78 \pm 0.11 \mathrm{c}$ & $34.70 \pm 0.54 \mathrm{a}$ & $7.75 \pm 0.12 \mathrm{~d}$ \\
\hline Carbohydrate & $9.67 \pm 1.04 \mathrm{~b}$ & $20.73 \pm 0.64 b$ & $23.3 \pm 0.53 \mathrm{a}$ & $22.94 \pm 0.74 \mathrm{a}$ \\
\hline
\end{tabular}

${ }^{1}$ Means followed by the same letter in the same row do not differ by the Tukey test at $5 \%$ probability $(\mathrm{n}=5)$ 
fiber since, according to ANVISA (Agência Nacional de Vigilância Sanitária, 2012), food with a content of $6 \%$ can be considered high in fiber. The Food and Drug Administration (FDA) recommends the consumption of $25 \mathrm{~g}$ total dietary fiber per day based on a 2000-calorie diet. In papaya peel flour is rich in insoluble fiber, and insoluble fiber is partially fermented accelerating intestinal transit and increasing fecal bulk. The results obtained for the flour of the peel from Havai and Calimosa papaya are higher than those reported by Silva et al. (2007), who reported fiber content between 14.45 and $19.57 \mathrm{~g}$ $100 \mathrm{~g}^{-1}$ for Papaya peels. With regard to the seed flour, the values found in the present study were lower than those obtained by

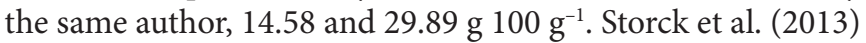
studied the nutritional composition of stems, peel, and seeds in

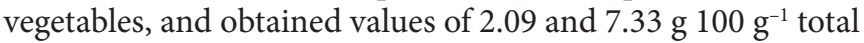
fiber for Papaya peel and seeds, respectively. The fiber content found for the seed is similar to that observed in this study.

The highest content of carbohydrate was found for Calimosa peel and seed flour (Table 1). Silva et al. (2007) found

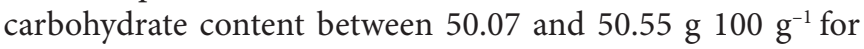
Papaya peels. For the seeds, the values were 17.97 and $22.45 \mathrm{~g}$ $100 \mathrm{~g}^{-1}$. The values reported by Rinaldi et al. (2010) for Formosa

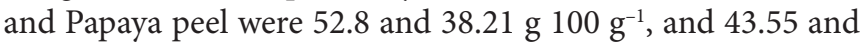

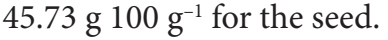

The proximate composition found in the samples of the present study is consistent with that reported by other authors. The small variations observed are probably due to differences in varieties, climate, crop and soil type, and fertility (Lee \& Kader, 2000). This shows the need for further studies on the chemical composition of different cultivars.

Table 2 presents the average values of the mineral composition of the flour from papaya peel and seed. Minerals are essential compounds for the maintenance of essential human body functions. The highest levels of $\mathrm{K}$ and $\mathrm{Cu}$ were observed in the peel flour, and the levels of $\mathrm{P}, \mathrm{Cl}, \mathrm{Mg}, \mathrm{S}, \mathrm{Zn}$, and Fe were higher in the seed flour.

No recent data on the mineral composition of papaya seeds were found in the literature. Hiroce et al. (1977) determined the mineral composition of papaya peel and seed in dry matter and obtained values similar to those found in the present study. Godim et al. (2005) analyzed the mineral composition of Papaya peels and reported values higher than those found for the peel flour from Havai and Calimosa papaya.

The RDI (Recommended Daily Intake) values of potassium, magnesium, iron, zinc, manganese, copper, phosphorus, and calcium for adults are $4.6 \mathrm{~g} /$ day, $260 \mathrm{mg} /$ day, $14 \mathrm{mg} /$ day, $7 \mathrm{mg} /$ day, $2.3 \mathrm{mg} /$ day, 900 g/day, $700 \mathrm{mg} /$ day, and $1000 \mathrm{mg} /$ day, respectively. Thus, the intake of $100 \mathrm{~g}$ papaya peel flour from the cultivar Havai, will supply 44\%, 81\%, 22\%, 47\%, 138\%, 121\%, $78 \%$, and $34 \%$ of potassium, magnesium, iron, zinc, manganese, copper, phosphorus, and calcium, respectively, and from the cultivar Calimosa it will supply 45\%, 70\%, 20\%, 37\%, $147 \%$, $126 \%, 75 \%$ and $30 \%$. On the other hand, for the papaya seed flour from the cultivar Havai, a 100-g intake will supply $16 \%$, $127 \%, 37 \%, 88 \%, 135 \%, 59 \%, 81 \%$, and $72.5 \%$ of potassium, magnesium, iron, zinc, manganese, copper, phosphorus, and calcium, respectively, and from the cultivar Calimosa it will supply $42 \%, 134 \%, 36 \%, 91 \%, 196 \%$, 92\%, and $78 \%$.

The results of the content of vitamin $\mathrm{C}$ and phenolic compounds obtained are presented in Table 3.

The peel flour from Havai and Calimosa papaya had higher concentrations of vitamin C (3.37 and $\left.2.96 \mathrm{mg} \mathrm{g}^{-1}\right)$ than that of the seed flour $\left(0.15\right.$ and $\left.0.12 \mathrm{mg} \mathrm{g}^{-1}\right)$. Oliveira et al. (2011) found an average content of vitamin $\mathrm{C}$ of $0.80 \mathrm{mg} \mathrm{g}^{-1}$ for the fresh pulp of Formosa papaya. The amounts of vitamin $\mathrm{C}$ in the present study, based on fresh matter, found in the peel flour (0.44 and

Table 2. Average values ${ }^{1}\left(\mathrm{mg} 100 \mathrm{~g}^{-1}\right)$ of the mineral composition of peel and seed flours from Havai and Calimosa papaya.

\begin{tabular}{|c|c|c|c|c|}
\hline & \multicolumn{2}{|c|}{ Havai } & \multicolumn{2}{|c|}{ Calimosa } \\
\hline & Peel & Seed & Peel & Seed \\
\hline Phosphorus & $547.50 \pm 14.79 \mathrm{ab}$ & $566.9 \pm 22.49 \mathrm{a}$ & $526.88 \pm 6.25 \mathrm{~b}$ & $545.00 \pm 16.58 \mathrm{ab}$ \\
\hline Potassium & $2,046.30 \pm 20.60 \mathrm{a}$ & $743.30 \pm 17.43 \mathrm{c}$ & $2,075.50 \pm 43,22 \mathrm{a}$ & $1,928.80 \pm 41.70 \mathrm{~b}$ \\
\hline Calcium & $337.50 \pm 10.90 \mathrm{c}$ & $725.00 \pm 26.46 \mathrm{~b}$ & $296.30 \pm 13.77 \mathrm{~d}$ & $780.00 \pm 27.39 \mathrm{a}$ \\
\hline Magnesium & $210.00 \pm 12.25 \mathrm{~b}$ & $332.50 \pm 8.29 \mathrm{a}$ & $182.50 \pm 9.57 \mathrm{c}$ & $347.50 \pm 8.29 \mathrm{a}$ \\
\hline Sulfur & $362.50 \pm 12.99 \mathrm{~b}$ & $338.10 \pm 17.72 \mathrm{c}$ & $406.30 \pm 16.00 \mathrm{a}$ & $357.50 \pm 8.29 \mathrm{bc}$ \\
\hline Copper & $1.09 \pm 0.07 \mathrm{a}$ & $0.53 \pm 0.02 \mathrm{c}$ & $1.14 \pm 0.08 \mathrm{a}$ & $0.83 \pm 0.05 \mathrm{~b}$ \\
\hline Manganese & $3.18 \pm 0.06 \mathrm{c}$ & $3.10 \pm 0.04 \mathrm{c}$ & $3.37 \pm 0.03 \mathrm{~b}$ & $4.51 \pm 0.08 \mathrm{a}$ \\
\hline Zinc & $3.28 \pm 0.06 c$ & $6.17 \pm 0.06 \mathrm{~b}$ & $2.6 \pm 0.07 \mathrm{~d}$ & $6.40 \pm 0.05 \mathrm{a}$ \\
\hline Iron & $3.02 \pm 0.03 \mathrm{c}$ & $5.23 \pm 0.03 \mathrm{a}$ & $2.85 \pm 0.04 \mathrm{~d}$ & $4.98 \pm 0.04 \mathrm{~b}$ \\
\hline
\end{tabular}

${ }^{1}$ Means followed by the same letter in the same row do not differ by the Tukey test at $5 \%$ probability $(n=5)$.

Table 3. Average values ${ }^{1}\left(\mathrm{mg} \mathrm{g}^{-1}\right)$ of the contents of vitamin C and phenolic compounds of peel and seed flours from Havai and Calimosa papaya.

\begin{tabular}{lcccc}
\hline & \multicolumn{2}{c}{ Havai } & \multicolumn{2}{c}{ Calimosa } \\
\cline { 2 - 5 } & Peel & Seed & Peel & Seed \\
\hline Vitamin C & $3.37 \pm 0.08 \mathrm{a}$ & $0.15 \pm 0.01 \mathrm{c}$ & $2.96 \pm 0.37 \mathrm{~b}$ & $0.12 \pm 0.01 \mathrm{c}$ \\
Phenolic compounds & $5.75 \pm 0.28 \mathrm{a}$ & $2.66 \pm 0.13 \mathrm{~b}$ & $5.53 \pm 0.14 \mathrm{a}$ & $3.01 \pm 0.50 \mathrm{~b}$ \\
\hline
\end{tabular}

${ }^{1}$ Means followed by the same letter in the same row do not differ by the Tukey test at $5 \%$ probability $(n=5)$. 
Table 4. Average values ${ }^{1}$ of the physicochemical and chemical characteristics of peel and seed flours from Havai and Calimosa papaya.

\begin{tabular}{lcccc}
\hline & \multicolumn{2}{c}{ Havai } & \multicolumn{2}{c}{ Calimosa } \\
\cline { 2 - 5 } & Peel & Seed & Peel & Seed \\
\hline Soluble solids & $5.75 \pm 0.56 \mathrm{a}$ & $1.25 \pm 0.00 \mathrm{~b}$ & $6.00 \pm 0.40 \mathrm{a}$ & $1.19 \pm 0.11 \mathrm{~b}$ \\
pH & $4.55 \pm 0.03 \mathrm{a}$ & $5.27 \pm 0.04 \mathrm{a}$ & $4.69 \pm 0.05 \mathrm{a}$ & $5.56 \pm 0.02 \mathrm{a}$ \\
Titratable acidity $^{3}$ & $0.80 \pm 0.01 \mathrm{a}$ & $0.26 \pm 0.04 \mathrm{c}$ & $0.63 \pm 0.04 \mathrm{~b}$ & $0.22 \pm 0.03 \mathrm{c}$ \\
\hline
\end{tabular}

${ }^{1}$ Means followed by the same letter in the same row do not differ by the Tukey test at $5 \%$ probability $(\mathrm{n}=5) ;{ }^{20} \mathrm{Brix} ;{ }^{3} \%$ citric acid.

$\left.0.40 \mathrm{mg} \mathrm{g}^{-1}\right)$ and in the seed flour $\left(0.007\right.$ and $\left.0.006 \mathrm{mg} \mathrm{g}^{-1}\right)$ for the cultivars Havai and Calimosa, respectively, showed that the pulp is richer in this vitamin than the flours. Sancho et al. (2010) determined the content of vitamin $\mathrm{C}$ in papaya from the cultivar Maradol and observed higher levels for the pulp $\left(0.60 \mathrm{mg} \mathrm{g}^{-1}\right)$, when compared to those of the peel $\left(0.24 \mathrm{mg} \mathrm{g}^{-1}\right)$. The Vitamin $\mathrm{C}$ contents found in the present study are higher than those observed by these authors. Rinaldi et al. (2010) found Vitamin $\mathrm{C}$ contents of 0.55 and $0.80 \mathrm{mg} \mathrm{g}^{-1}$ for the peel of Papaya and Formosa papaya and, contents of 0.65 and $0.79 \mathrm{mg} \mathrm{g}^{-}$for the seed ${ }^{1}$. These values are higher than those found for the peel and seed flour from the cultivars Havai and Calimosa.

The peel flour showed higher contents of phenolic compounds than those of the seed flour for both cultivars, but neither of the two fractions showed significant amounts of these compounds. Oliveira et al. (2011) found an average value of $0.881 \mathrm{mg} \mathrm{g}^{-1}$ of phenolic compounds in Formosa pulps. The results of the peel flour $\left(0.76 \mathrm{mg} \mathrm{g}^{-1}\right)$ and of the seed flour $(0.14$ and $0.17 \mathrm{mg}^{-1}$ ) obtained in the present study for Havai and Calimosa papaya, based on fresh matter, are lower than those presented by those authors in the pulp. Papaya has low levels of phenolic compounds.

Phenolic compounds have a high antioxidant potential, resulting in a beneficial effect on health although these compounds can contribute to changes in taste and color of food products (Sancho et al., 2010). The same authors determined the content of phenolic compounds in Maradol papaya and found higher content for the peel $\left(1.9 \mathrm{mg} \mathrm{g}^{-1}\right)$ than the content obtained in the present study, based on fresh matter.

Table 4 shows the average values of the following physicochemical and chemical characteristics: $\mathrm{pH}$, acidity, and soluble solids in papaya peel and seed flours:

The titratable acidity of the peel flour was higher than that of the seed flour for both cultivars and is lower than that observed by Rinaldi et al. (2010), who found values between 2.6 and $3.0 \%$ in the peel and $2.5 \%$ in the seed of Papaya and Formosa papaya.

It can be seen that $\mathrm{pH}$ is an auxiliary parameter for the evaluation of titratable acidity, and this parameter is an important indicator in the assessment of the conservation status of a food product. The $\mathrm{pH}$ values close to 4.5 can prevent the growth of microorganisms (Queiroz et al., 2012). The $\mathrm{pH}$ value found for the papaya peel flour in both cultivars was close to 4.5. Thus, the dried peel can be considered as acidic powder food that offers antimicrobial resistance. Rinaldi et al. (2010) obtained $\mathrm{pH}$ values between 5.4 and 5.6 in the peel, and 5.8 in the seed for the cultivars Formosa and Papaya. The $\mathrm{pH}$ values of both types of papaya are in agreement with the values reported in the literature, which are between 5.5 and 5.9, while the values of titratable acidity were higher than those found for papaya pulp (Alves et al., 2003). According to Alves et al. (2003), the acidity of papaya is low, approximately $0.1 \%$.

The content of soluble solids is an indicative of the contents of soluble sugars present in foods, and therefore of their sweetness, and it is influenced by many factors, such as cultivar, climate, and soil among others (Queiroz et al., 2012). For this variable, higher values of the peel flour (5.75 and $\left.6.0^{\circ} \mathrm{Brix}\right)$ were obtained, and they are lower than those reported by Rinaldi et al. (2010), who observed contents between 8.1 and $9.9^{\circ}$ Brix for the cultivars Formosa and Papaya. The same authors reported a higher value for seeds $\left(6.3^{\circ}\right.$ Brix) than those found in the present study (Table 4).

The by-products papaya seed and peel have high a nutritional potential and can be used as alternative sources of nutrients since they do not have antinutritional factors in amounts that are harmful to the body, which reinforces the need for the determination of these antinutrients in these flours in future studies.

\section{Conclusion}

Analyzing all the results, it was observed that papaya peel flour stood out for the following parameters: fiber, ash, phenolic compounds, vitamin $\mathrm{C}$, soluble solids, titratable acidity, and the minerals copper, sulfur, and potassium. On the other hand, papaya seed flour stood out for protein, lipids, and the minerals calcium, iron, magnesium, and zinc.

The knowledge about the chemical composition of papaya peel and seeds subjected to drying provides useful information for industries interested in using papaya by-products, reducing waste, and adding value to the fruit bringing benefits to the environment.

Both the peel and the seed flour can be used in food products.

\section{Acknowledgements}

The authors are grateful for the financial support provided by FAPEMIG - Minas Gerais State Research Foundation, CAPES - Coordination for the Improvement of Higher Education Personnel, CNPq - The National Council for Scientific and Technological Development. 


\section{References}

Agência Nacional de Vigilância Sanitária - Anvisa. (2012). Dispõe sobre o Regulamento Técnico sobre Informação Nutricional Complementar (Resolução RDC nº 54, de 12 de novembro de 2012). Diário Oficial da União. Retrieved from http://portal.anvisa.gov. br/wps/wcm/connect/630a98804d7065b981f1e1c116238c3b/ Resolucao+RDC+n.+54_2012.pdf?MOD=AJPERES

Alves, F. L., Balbino, J. M. S., \& Barreto, F. C. (2003). A cultura do mamoeiro: tecnologias de produção. Vitoria: Incaper.

Association of Official Analytical Chemists - AOAC. (2012). Official methods of analysis of AOAC International (19th ed.). Gaithersburg: AOAC International.

Djilas, S., Canadanovic-Brunet, J., \& Cetkovic, G. (2009). By-products of fruits processing as a source of phytochemicals. Chemical Industry and Chemical Engineering Quarterly, 15(4), 191-202. http://dx.doi. org/10.2298/CICEQ0904191D

Godim, J. A. M., Moura, M. F. V., Dantas, A. S., Medeiros, R. L. S., \& Santos, K. M. (2005). Composição centesimal e de minerais em cascas de frutas. LWT-Food Science and Technology, 25(4), 825-827.

Hiroce, R., Carvalho, A. M., Bataglia, O. C., Furlani, P. R., Furlani, A. M. C., Santos, R. R., Pariquera, E. E. A., \& Gallo, J. R. (1977). Composição mineral de frutos tropicais na colheita. Bragantia, 36(14), 155-164.

Informa Economics FNP. (2011). Anuário da agricultura brasileira. São Paulo.

Instituto Adolfo Lutz - IAL. (2005). Normas analíticas, métodos químicos e físicos para análises de alimentos (3. ed.). São Paulo.

Lee, S. K., \& Kader, A. A. (2000). Preharvest and postharvest factors influencing vitamin $\mathrm{C}$ content of horticultural crops. Postharvest Biology and Technology, 20(3), 207-220. http://dx.doi.org/10.1016/ S0925-5214(00)00133-2

Malavolta, E., Vitti, G. C., \& Oliveira, A. S. (1997). Avaliação do estado nutricional das plantas. Piracicaba: POTAFOS.
Oliveira, D. S., Aquino, P. P., Ribeiro, S. M. R., Proença, R. P. C., \& Pinheiro-Sant'Ana, H. M. (2011). Vitamina C, carotenoides, fenólicos totais e atividade antioxidante de goiaba, manga e mamão procedentes da Ceasa do Estado de Minas Gerais. Acta Scientiarum: Health Sciences, 33(1), 89-98. http://dx.doi. org/10.4025/actascihealthsci.v33i1.8052

Queiroz, E. R., Abreu, C. M. P., \& Oliveira, K. S. (2012). Constituintes químicos das frações de lichia in natura e submetidas à secagem: potencial nutricional e dos subprodutos. Revista Brasileira de Fruticultura, 34(4), 1174-1179. http://dx.doi.org/10.1590/S010029452012000400026

R Core Team. (2013). R: a language and environment for statistical computing. Vienna: R Foundation for Statistical Computing. Retrieved from http://www.R-project.org/

Rinaldi, M. M., Lima, T. A., \& Ascheri, D. P. R. (2010). Caracterização física de frutos de mamão e química de cascas e sementes. Planaltina: Embrapa Cerrados. Boletim de Pesquisa e Desenvolvimento 263.

Sancho, L. E. G. G., Yahia, E. M., \& González-Aguilar, G. A. (2010). Identification and quantification of phenols, carotenoids, and vitamin $\mathrm{C}$ from papaya (Carica papaya L., cv. Maradol) fruit determined by HPLC-DAD-MS/MS-ESI. Food Research International, 44(5), 1284-1291. http://dx.doi.org/10.1016/j. foodres.2010.12.001

Serrano, L. A. L., \& Cattaneo, L. F. (2010). O cultivo do mamoeiro no Brasil. Revista Brasileira de Fruticultura, 32(3). http://dx.doi. org/10.1590/S0100-29452010000300001

Silva, G. G., Diniz, R. G., \& Silva, M. E. (2007). Avaliação química do mamão papaia (Carica papaya L.) em diferentes estádios de maturação. Revista Capixaba de Ciência e Tecnologia, (3), 1-7.

Storck, C. R., Nunes, G. L., Oliveira, B. B., \& Basso, C. (2013). Folhas, talos, cascas e sementes de vegetais: composição nutricional, aproveitamento na alimentação e análise sensorial de preparações. Ciência Rural, 43(3), 537-543. http://dx.doi.org/10.1590/S010384782013000300027

Strohecker, R., \& Henning, H. M. (1967). Analisis de vitaminas: métodos comprobados. Madrid: Paz Montalvo. 


\section{Erratum}

Due to a desktop publishing error in the article "Chemical characterization of the flour of peel and seed from two papaya cultivars"

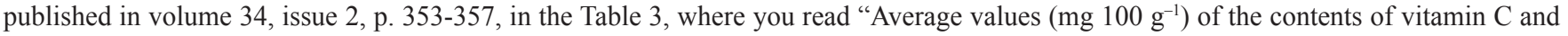
phenolic compounds of peel and seed flours from Havai and Calimosa papaya", should read "Average values (mg g $\left.\mathrm{g}^{-1}\right)$ of the contents of vitamin $\mathrm{C}$ and phenolic compounds of peel and seed flours from Havai and Calimosa papaya". 